\title{
Genetic divergence among pumpkin landraces
}

\section{Divergência genética entre variedades crioulas de abóbora}

\author{
Rebeca Lourenço de Oliveira ${ }^{1}$; Leandro Simões Azeredo Gonçalves ${ }^{2 *}$; \\ Rosana Rodrigues ${ }^{3}$; Viviane Yumi Baba ${ }^{4}$; Cláudia Pombo Sudré5; \\ Marilene Hilma dos Santos ${ }^{6}$; Fabrizio Malaghini Aranha ${ }^{4}$
}

\begin{abstract}
Estimating the genetic variability in germplasm collections is important not only for conserving genetic resources, but also for plant breeding purposes. However, generating a large number of different categories data (qualitative and quantitative) often complicate the analysis and results interpretation, resulting in an incomplete distinction of accessions. This study reports the characterization and evaluation of 14 pumpkin (Cucurbita moschata) accessions collected from farms in the northern region of Rio de Janeiro state. Genetic diversity among accessions was also estimated using qualitative and quantitative variables considering joint analysis. The plants were grown under field conditions in a randomized block design with three replications and six plants per plot. Eight qualitative traits (leaf size; seed shape; seed color; color of the fruit pulp; hollow; fruit shape; skin color, and fruit skin texture) and eight quantitative traits (fruit weight; fruit length; fruit diameter; soluble solids, 100 seed weight, and wall thickness measured in the middle and in the lower stem) were evaluated. The data were analyzed considering the Gower distance, and cluster analysis was performed using unweighted pair group method with arithmetic mean (UPGMA). Variability among accessions was observed considering morphoagronomic data. The Gower distance together with UPGMA cluster allowed for good discrimination between accessions in the groups, demonstrating that the simultaneous analysis of qualitative and quantitative data is feasible and may increase the understanding of the variation among accessions.
\end{abstract}

Key words: Cucurbita moschata. Gower distance. Morphoagronomic descriptors. Multivariate analyses.

\section{Resumo}

A estimativa da variabilidade genética em banco de germoplasma é importante não só para conservação dos recursos genéticos, mas também para sua utilização no melhoramento de plantas. Entretanto, a geração de um grande número de variáveis de diferentes categorias (qualitativas e quantitativas) pode dificultar a análise e a interpretação dos resultados, muitas vezes resultando na incompleta distinção dos acessos. Este trabalho objetivou caracterizar 14 acessos de Cucurbita moschata coletados no Norte do Estado do Rio de Janeiro e estimar a divergência genotípica entre esses acessos, utilizando a análise conjunta de variáveis qualitativas e quantitativas. As plantas foram cultivadas a campo, no delineamento de blocos ao acaso, com três repetições e seis plantas por parcela. Foram avaliadas

${ }^{1}$ Eng $^{\mathrm{a}}$ Agr ${ }^{\mathrm{a}}$, Universidade Estadual do Norte Fluminense Darcy Ribeiro, UENF, Campos dos Goytacazes, RJ, Brasil. E-mail: rebecalourencoo@gmail.com

2 Prof. Adjunto, Universidade Estadual de Londrina, UEL, Londrina, PR. E-mail: leandrosag@uel.br

${ }^{3}$ Prof ${ }^{a}$ Associado, UENF, Campos dos Goytacazes, RJ, Brasil. E-mail: rosana@uenf.br

${ }^{4}$ Mestres em Agronomia, UEL, Londrina, PR, Brasil. E-mail: vybaba15@gmail.com; fabrizioaranha7@hotmail.com

${ }^{5} \mathrm{Dr}^{\mathrm{a}}$ em Genética e Melhoramento de Plantas, UENF, Campos dos Goytacazes, RJ, Brasil. E-mail: cpombo@uenf.br

${ }^{6}$ Prof ${ }^{a}$ Adjunta, Universidade Federal Rural do Rio de Janeiro, UFrRJ, Seropédica, RJ, Brasil. E-mail: mhsantos_20@yahoo.com. br

* Author for correspondence 
oito variáveis qualitativas (tamanho da folha; formato da semente; cor da semente; cor da polpa do fruto; reentrância; formato do fruto; cor predominante da casca e textura da superfície da casca) e oito variáveis quantitativas (massa do fruto; comprimento e diâmetro do fruto; teor de sólidos solúveis totais; massa de 100 sementes, e espessura da polpa no pedúnculo, mediana e inferior). Os dados foram analisados considerando a distância de Gower e o agrupamento dos acessos foi realizado pelo método UPGMA. Verificou-se variabilidade entre os acessos coletados e a distância de Gower, juntamente com agrupamento UPGMA, permitiu a discriminação dos acessos nos grupos, demonstrando que análise simultânea de variáveis é viável e permite maior eficiência no conhecimento da variabilidade entre os acessos avaliados.

Palavras-chave: Cucurbita moschata. Análise multivariada. Descritores morfoagronômicos. Distância de Gower.

\section{Introduction}

Among vegetable crops, pumpkin (Cucurbita spp.) is considered a staple food for the Brazilian population, and it is a vegetable with socioeconomic and nutritional importance (BLANK et al., 2013; CARVALHO et al., 2011). Specifically in Rio de Janeiro state, vegetable crop production is a highly dynamic agricultural branch, with intensive activity in small areas and pumpkin is cultivated mostly by family farmers who have selected local varieties suited to their edaphoclimatic conditions for several generations (SANTOS et al., 2012). However, the competition for productivity and market product quality encourages these producers to use genotypes that are already available on the market and to neglect traditional germplasm cultivation. These local varieties are important for agrobiodiversity, and their disuse has increased the degree of genetic erosion.

The loss of traditional germplasms is concerning to breeders working towards sustainable agriculture. The implementation of collecting activities, characterization, and evaluation of these accessions will enable the maintenance of genetic variability and the availability of this variability for breeding programs (CABRAL et al., 2010; GONÇALVES et al., 2008; SUDRÉ et al., 2010).

During the characterization and evaluation of accessions, the generation of a large number of data from different categories (qualitative and quantitative) may limit analysis and interpretation of the results, often resulting in the incomplete distinction of accessions. Jointly analyzing quantitative and qualitative variables can provide a better indication of existing variability (ROCHA et al., 2010). Gower's distance (1971) is a lowcomplexity joint analysis procedure which has been used in several characterization and evaluation studies of germplasms (BERTAN et al., 2009; GONÇALVES et al., 2008; MOURA et al., 2010; QUINTAL et al., 2012; ROCHA et al., 2010; RODRÍGUEZ et al., 2005; TSIVELIKAS et al., 2009; VIEIRA et al., 2007).

Therefore, in this study, we conducted joint analysis to characterize and evaluate the genotypic divergence of 14 accessions of Cucurbita moschata collected in the northern region of the State of Rio de Janeiro using qualitative and quantitative variables.

\section{Material and Methods}

The experiment was carried out in the field at the Unidade de Apoio à Pesquisa from Centro de Ciências e Tecnologias Agropecuárias of Universidade Estadual do Norte Fluminense Darcy Ribeiro (UENF), located in Campos dos Goytacazes, Rio de Janeiro. Fourteen Cucurbita moschata accessions collected in the municipalities of Campos dos Goytacazes and São João da Barra in the northern Region of the Rio de Janeiro State were evaluated (Table 1).

Seedlings were grown in Styrofoam trays containing 72 cells filled with a commercial substrate for vegetables (Plantimax ${ }^{\circledR}$ Organix Phils 
Corp., Molino, Philippines). Thirty-six seeds of each accession were sown in order to obtain 18 seedlings for planting. After 15 days, the seedlings were transplanted to the field and arranged in a randomized complete block with three replicates and six plants per plot. Plants were spaced at $1.5 \mathrm{~m}^{\prime} 1.5$ $\mathrm{m}$. Fertilization was carried out in accordance with the analysis of the soil and the recommendations for the crop according to De-Polli (1990). Crop treatments were carried out in accordance with the culture recommendations (FILGUEIRA, 2000).

Table 1. Passport data of 14 pumpkin landrace (Cucurbita moschata) collected in the northern region of the Rio de Janeiro state.

\begin{tabular}{|c|c|c|}
\hline Accession & Common Name & Origin \\
\hline UENF 1862 & Neck Pumpkin & São João da Barra - RJ \\
\hline UENF 1864 & Pumpkin & São João da Barra - RJ \\
\hline UENF 1890 & Common Pumpkin & Cazumbá - Campos dos Goytacazes - RJ \\
\hline UENF 1881 & Common Pumpkin & Baixa Grande - Campos dos Goytacazes - RJ \\
\hline UENF 1879 & Pumpkin Baianinha & Oziel Alves settlement - Campos dos Goytacazes - RJ \\
\hline UENF 1895 & Pumpkin Baianinha & - \\
\hline UENF 1893 & Pumpkin & Campo de Areia - Campos dos Goytacazes - RJ \\
\hline UENF 1889 & Caravela Pumpkin & Serra do Mico - Campos dos Goytacazes - RJ \\
\hline UENF 1883 & Common Pumpkin & Zumbi IV settlement - Campos dos Goytacazes - RJ \\
\hline UENF 1878 & Sergipe Pumpkin & Oziel Alves settlement - Campos dos Goytacazes - RJ \\
\hline UENF 1885 & Sergipe Pumpkin & São Luiz de Mutuca - Campos dos Goytacazes - RJ \\
\hline UENF 1872 & Common Pumpkin & - \\
\hline UENF 1886 & Common Pumpkin & São Luiz de Mutuca - Campos dos Goytacazes - RJ \\
\hline UENF 1875 & Cascadura Pumpkin & Bajuru - São João da Barra - RJ \\
\hline
\end{tabular}

During flower emergence, which occurred 75 days after planting, controlled pollination (sisterbrother, SIB) was performed to maintain the germplasm. For this step, female and male flowers were lashed with wool before anthesis. The following day, the male flower was detached, removing its corolla and touching the anther on the stigma of the female flower. Open pollination also occurred, and the fruits from the two pollination systems were harvested separately for seed extraction. Four harvests were performed.

In accordance with the list of morphoagronomic descriptors proposed by Esquinas-Alcazar and Gulick (1983), eight qualitative characteristics were evaluated, including: leaf size (3: small, 5: intermediate, and 7: large); seed shape (1: very sharp elliptical, 3: sharp elliptical, and 5: elliptical); external color of seed (1: whitish, 2: yellowish, and
3: brownish); color of fruit flesh (1: cream, 2: yellow 3: orange, and 4: orange reddish); ribs (1: absent, 3: superficial, 5: intermediate, and 7: deep); fruit shape (1: globular, 2: flattened, 3: disc 4: oblong, 5: elliptical, 6: cordiform, 7: pyriform, 8: dumbbell, 9: elongate forms, 10: turbinate superior, 11: crowned, 12: turbinate bottom, 13: curved, and 14: crooked neck); predominant fruit skin color (1: cream, 2: yellow 3: orange, 4: pink, 5: red 6: green 7: graygreen, and 8: gray); and fruit skin texture (1: smooth and 2: rough). Eight quantitative characteristics were evaluated, including: fruit mass $(\mathrm{kg})$; length and diameter of the fruit $(\mathrm{cm})$; total soluble solids content (determined by refractometer in a sample of juice extracted from the pulp of the ripe fruit and measured in Brix degrees); weight of 100 seeds, and peduncle, median, and lower flesh thickness $(\mathrm{cm})$. 
Quantitative variables were analyzed using univariate analysis and the means were grouped using the Scott-Knott test (1974). A distance matrix was estimated based on Gower's algorithm (1971), which is expressed by:

$$
d_{i j}=\frac{\sum_{k=1}^{p} w_{i j k} d_{i j k}}{\sum_{k=1}^{p} w_{i j k}},
$$

where $\mathrm{K}$ is the number of variables $(\mathrm{k}=1,2, \ldots, \mathrm{p}=$ total number of analyzed variables), $i$ and $j$ any two individuals; $W_{i j k}$ is a weight given to compare $i j k$, assigning value 1 for valid comparisons and value 0 for invalid comparisons (when the value of the variable is missing in one or both individuals), and $d_{i j k}$ is the contribution of the variable $k$ in similarity between individuals $i$ and $j$ with values between 0 and 1. For a nominal variable, if the value of the variable $\mathrm{k}$ is the same for both individuals, $i$ and $j$, then $d_{i j k}=1$, otherwise, this value is 0 ; for a continuous variable

$$
d_{i j}=\frac{\left|y_{k}-y_{k}\right|}{R_{k}},
$$

where $y_{i k}$ and $y_{j k}$ are the values of the variable $k$ for individuals $i$ and $j$, respectively, and $R_{k}$ is the amplitude of variation of the variable $\mathrm{k}$ in the sample. The division by $R_{k}$ eliminates the differences between scales of variables, producing a value within the range $[0,1]$ with equal weights.

The accessions were grouped using unweighted pair-group method with arithmetic mean (UPGMA), nearest neighbor, and Ward methods. The groups were validated based on the cophenetic correlation coefficient. The statistical program $\mathrm{R}$ was used for analysis (http://www.r-project.org).

\section{Results and Discussion}

Variability was observed in qualitative morphoagronomic variables among the studied accessions (Table 2). For leaf size, most of the accessions (57.14\%) were of intermediate size, followed by $35.71 \%$ and $7.15 \%$ with large and small leaves, respectively. The same variability was observed for seed format; $57.14 \%$ of the accessions had sharp elliptical seeds and 35.71\% and $7.15 \%$ had elliptical and very sharp elliptical seeds, respectively. For seed color, 64.29\% samples showed brown color and $35.71 \%$ whitish color.

Large variability was observed in the assessment of the ribs, both in the presence and the intensity of fruit ribs. Two accessions (UENF 1862 and UENF 1864) had no ribs, six accessions (UENF 1872, UENF 1878, UENF 1879, UENF 1881, UENF 1883, and UENF 1890) had superficial ribs, four accessions (UENF 1875, UENF 1885, UENF 1886, and UENF 1895) had intermediate ribs, and two accessions (UENF 1889 and UENF 1893) had deep ribs. According to Santos (2013), the absence of ribs on fruit surface can facilitate the marketing of cut fruit because it allows for cutting of the flesh in more regular sections. For the texture of the skin surface, smooth skin was observed more commonly (78.57\%) than rough skin $(21.43 \%)$.

High variation was also observed in the shape of the fruit between accessions, with $35.71 \%$ globular, $28.57 \%$ pyriform, $21.43 \%$ elliptical, and $14.29 \%$ cordiform. The genetic inheritance of the shape and size of the fruit was defined as polygenic, with two genes having major effects, including $B n$ and $D i$. The gene $B n$ (butternut) determines the cylindrical shape or bell-shape form, while the recessive $b n-$ (crookneck) determines fruit with apex. The gene $D i$ (disc fruit shape) determines whether the fruit is globular-shaped or pear-shaped (PARIS; BROWN, 2005; PARIS; PADLEY JÚNIOR, 2014). 
Table 2. Morphoagronomic characterization of eight qualitative variables in 14 pumpkins landrace collected in the northern region of the Rio de Janeiro state.

\begin{tabular}{|c|c|c|c|c|c|c|c|c|}
\hline \multirow{2}{*}{ Acessions } & \multicolumn{8}{|c|}{ Qualitative morphoagronomic characteristics ${ }^{1 /}$} \\
\hline & $\mathrm{LS}$ & SS & ECS & $\mathrm{CF}$ & RI & FS & $\mathrm{PC}$ & STS \\
\hline $\begin{array}{c}\text { UENF } \\
1862\end{array}$ & Intermediate & $\begin{array}{l}\text { Sharp } \\
\text { elliptic }\end{array}$ & Brownish & Orange & Absent & Pyriform & Orange & Rough \\
\hline $\begin{array}{l}\text { UENF } \\
1864\end{array}$ & Intermediate & Elliptical & Brownish & Orange & Absent & Elliptical & Orange & Smooth \\
\hline $\begin{array}{c}\text { UENF } \\
1890\end{array}$ & Intermediate & Elliptical & Whitish & Orange & Superficial & Pyriform & Gray & Smooth \\
\hline $\begin{array}{c}\text { UENF } \\
1881\end{array}$ & Large & $\begin{array}{l}\text { Sharp } \\
\text { elliptic }\end{array}$ & Brownish & Orange & Superficial & Elliptical & Green & Rough \\
\hline $\begin{array}{c}\text { UENF } \\
1879\end{array}$ & Intermediate & Elliptical & Brownish & Orange & Superficial & Pyriform & Green & Smooth \\
\hline $\begin{array}{l}\text { UENF } \\
1895\end{array}$ & Intermediate & Elliptical & Brownish & Orange & Intermediate & Globular & Green & Smooth \\
\hline $\begin{array}{c}\text { UENF } \\
1893\end{array}$ & Large & $\begin{array}{l}\text { Sharp } \\
\text { elliptic }\end{array}$ & Whitish & Orange & Deep & Cordiform & Green & Smooth \\
\hline $\begin{array}{c}\text { UENF } \\
1889\end{array}$ & Large & Elliptical & Brownish & Orange & Deep & Globular & Cream & Smooth \\
\hline $\begin{array}{c}\text { UENF } \\
1883\end{array}$ & Intermediate & $\begin{array}{l}\text { Sharp } \\
\text { elliptic }\end{array}$ & Whitish & Orange & Superficial & Globular & Green & Smooth \\
\hline $\begin{array}{c}\text { UENF } \\
1878\end{array}$ & Large & $\begin{array}{l}\text { Sharp } \\
\text { elliptic }\end{array}$ & Whitish & $\begin{array}{l}\text { Reddish } \\
\text { Orange }\end{array}$ & Superficial & Globular & Green & Smooth \\
\hline $\begin{array}{c}\text { UENF } \\
1885\end{array}$ & Intermediate & $\begin{array}{l}\text { Sharp } \\
\text { elliptic }\end{array}$ & Brownish & Orange & Intermediate & Cordiform & Orange & Smooth \\
\hline $\begin{array}{c}\text { UENF } \\
1872\end{array}$ & Intermediate & $\begin{array}{l}\text { Sharp } \\
\text { elliptic }\end{array}$ & Brownish & Orange & Superficial & Elliptical & Green & Smooth \\
\hline $\begin{array}{l}\text { UENF } \\
1886\end{array}$ & Large & $\begin{array}{l}\text { Sharp } \\
\text { elliptic }\end{array}$ & Whitish & $\begin{array}{l}\text { Reddish } \\
\text { Orange }\end{array}$ & Intermediate & Globular & Orange & Smooth \\
\hline $\begin{array}{c}\text { UENF } \\
1875\end{array}$ & Small & $\begin{array}{c}\text { Very Sharp } \\
\text { Elliptical }\end{array}$ & Brownish & $\begin{array}{c}\text { Reddish } \\
\text { Orange }\end{array}$ & Intermediate & Pyriform & Orange & Rough \\
\hline
\end{tabular}

${ }^{1 /}$ LS: leaf size, SS: seed shape, ECS: external color of seed, CF: color of the flesh of the fruit, RI: ribs, FS: fruit shape, PC: predominant color of skin, and STS: surface texture of skin (1: smooth and 2: rough).

The color of the fruit pulp varied less between the studied accessions, with a predominance of orange color $(78.57 \%)$ followed by reddish orange color $(21.43 \%)$, while for the predominant fruit skin color, $50 \%$ of the accessions were green, $35.72 \%$ orange, $7.14 \%$ cream, and $7.14 \%$ graygreen. The color of the flesh and the skin of the fruit were determined to be complete heritage characters, since genes contributing to the intensity of color have been identified. For example, $L-2>$ $L-2{ }^{w}>l-2$ results in pale coloring of fruits, $W$ in weak staining of the fruit, and $D$ in dark color of the fruit. In addition, some genes are known to be responsible for color distribution patterns (Mldg weak mottling and strong green in immature fruit) and the color of the pigment ( $G r$ - green, $g r-$ straw yellow, $B l$ - blue) (PARIS; BROWN, 2005; PARIS; PADLEY JÚNIOR, 2014).

All characteristics analyzed by univariate variance expressed significant differences $(\mathrm{P}<0.01)$ among the accessions evaluated and, therefore, presented evidence of dissimilarity between the studied accessions (Table 3). According to ScottKnott test (1974) at a $1 \%$ level of significance, fruit mass, mass of 100 seeds, peduncle, and median 
flesh thickness showed the highest variability and formed three groups, followed by fruit length, fruit diameter, and total soluble solids content, which formed two groups (Table 2). For pulp thickness, all accessions were allocated into the same group, despite the significant differences revealed by the $\mathrm{F}$ test (Table 2).

Table 3. Mean grouping by the Scott-Knott test of 14 pumpkin landrace for eight agronomic descriptors.

\begin{tabular}{ccccccccc}
\hline \multirow{2}{*}{ Accession } & \multicolumn{7}{c}{ Agronomic characteristics ${ }^{1 /}$} \\
\cline { 2 - 8 } & MASS & LENGTH & DIAM & TSS & M100 & EPP & EPM & EPI \\
\hline UENF 1862 & $1.44^{2 /}$ & $21.19 \mathbf{a}$ & $13.24 \mathbf{b}$ & $7.77 \mathbf{a}$ & $10.51 \mathbf{b}$ & $8.79 \mathbf{b}$ & $1.52 \mathbf{c}$ & $1.61 \mathbf{a}$ \\
UENF 1864 & $1.33 \mathbf{c}$ & $16.63 \mathbf{b}$ & $13.62 \mathbf{b}$ & $9.43 \mathbf{a}$ & $7.31 \mathbf{c}$ & $3.08 \mathbf{c}$ & $1.87 \mathbf{c}$ & $1.61 \mathbf{a}$ \\
UENF 1890 & $1.67 \mathbf{c}$ & $15.23 \mathbf{b}$ & $14.38 \mathbf{b}$ & $5.53 \mathbf{b}$ & $8.88 \mathbf{b}$ & $3.88 \mathbf{c}$ & $2.29 \mathbf{c}$ & $2.19 \mathbf{a}$ \\
UENF 1881 & $1.55 \mathbf{c}$ & $16.19 \mathbf{b}$ & $14.46 \mathbf{b}$ & $7.33 \mathbf{a}$ & $9.73 \mathbf{b}$ & $2.55 \mathbf{c}$ & $1.81 \mathbf{c}$ & $1.63 \mathbf{a}$ \\
UENF 1879 & $2.09 \mathbf{c}$ & $19.18 \mathbf{a}$ & $15.11 \mathbf{b}$ & $4.77 \mathbf{b}$ & $15.55 \mathbf{a}$ & $3.29 \mathbf{c}$ & $1.74 \mathbf{c}$ & $1.94 \mathbf{a}$ \\
UENF 1895 & $1.05 \mathbf{c}$ & $10.26 \mathbf{b}$ & $14.33 \mathbf{b}$ & $7.18 \mathbf{a}$ & $4.59 \mathbf{c}$ & $3.99 \mathbf{c}$ & $1.96 \mathbf{c}$ & $1.09 \mathbf{a}$ \\
UENF 1893 & $3.00 \mathbf{b}$ & $16.52 \mathbf{b}$ & $18.31 \mathbf{a}$ & $4.90 \mathbf{b}$ & $10.06 \mathbf{b}$ & $3.07 \mathbf{c}$ & $3.05 \mathbf{b}$ & $3.07 \mathbf{a}$ \\
UENF 1889 & $4.79 \mathbf{a}$ & $18.87 \mathbf{a}$ & $22.51 \mathbf{a}$ & $4.03 \mathbf{b}$ & $8.72 \mathbf{b}$ & $4.39 \mathbf{c}$ & $4.39 \mathbf{a}$ & $2.38 \mathbf{a}$ \\
UENF 1883 & $1.52 \mathbf{c}$ & $14.91 \mathbf{b}$ & $14.57 \mathbf{b}$ & $5.02 \mathbf{b}$ & $7.68 \mathbf{c}$ & $2.74 \mathbf{c}$ & $2.07 \mathbf{c}$ & $1.91 \mathbf{a}$ \\
UENF 1878 & $4.09 \mathbf{a}$ & $22.37 \mathbf{a}$ & $22.00 \mathbf{a}$ & $5.57 \mathbf{b}$ & $5.84 \mathbf{c}$ & $3.21 \mathbf{c}$ & $2.53 \mathbf{c}$ & $2.52 \mathbf{a}$ \\
UENF 1885 & $2.93 \mathbf{b}$ & $24.51 \mathbf{a}$ & $17.35 \mathbf{a}$ & $5.23 \mathbf{b}$ & $5.74 \mathbf{c}$ & $3.60 \mathbf{c}$ & $2.59 \mathbf{c}$ & $2.24 \mathbf{a}$ \\
UENF 1872 & $1.38 \mathbf{c}$ & $15.27 \mathbf{b}$ & $13.46 \mathbf{b}$ & $5.00 \mathbf{b}$ & $9.73 \mathbf{b}$ & $2.01 \mathbf{c}$ & $2.09 \mathbf{c}$ & $1.92 \mathbf{a}$ \\
UENF 1886 & $2.94 \mathbf{b}$ & $13.76 \mathbf{b}$ & $20.42 \mathbf{a}$ & $5.43 \mathbf{b}$ & $4.62 \mathbf{c}$ & $1.97 \mathbf{c}$ & $3.15 \mathbf{b}$ & $2.43 \mathbf{a}$ \\
UENF 1875 & $0.97 \mathbf{c}$ & $21.43 \mathbf{a}$ & $10.62 \mathbf{b}$ & $8.77 \mathbf{a}$ & $11.28 \mathbf{b}$ & $11.79 \mathbf{a}$ & $1.21 \mathbf{c}$ & $1.05 \mathbf{a}$ \\
\hline Media $^{2.19}$ & 17.59 & 16.03 & 6.15 & 8.58 & 4.40 & 2.31 & 1.97 \\
\hline QMT $^{2 /}$ & $4.16^{* *}$ & $44.58^{* *}$ & $37.93^{* *}$ & $8.07^{* *}$ & $26.32^{* *}$ & $22.68^{* *}$ & $1.98^{* *}$ & $0.92^{* *}$ \\
\hline CVe $^{3 /}$ & 17.51 & 16.06 & 12.69 & 15.51 & 18.81 & 20.23 & 19.85 & 21.74 \\
\hline
\end{tabular}

${ }^{1 /}$ MASS: fruit mass, LENGHT: fruit length, DIAM: diameter of the fruit, TSS: total soluble solids content, M100: mass of 100 seeds, EPP: pulp thickness in peduncle, EPM: pulp thickness median, and EPI: pulp thickness bottom; ${ }^{2 /}$ QMT: mean squares method, and ${ }^{* *}$ : significant at $1 \%$ probability level by F test; ${ }^{3 /} \mathrm{CVe}$ : coefficient of experimental variation. ${ }^{2 /}$ Scott-Knott test (1974) at $1 \%$ probability.

Fruit mass ranged from 0.97 to $4.79 \mathrm{~kg}$ in accessions UENF 1875 and UENF 1889. In market terms, some surveys have recorded the preference of consumers for specific sizes of pumpkins. Consumers in the northeastern region of Brazil prefer fruit with masses ranging from 1.0 to $3.0 \mathrm{~kg}$, which facilitates the storage and consumption of the fruit (PEIXOTO, 1987). However, unlike other vegetables, pumpkin can be cut and sold in pieces of varying sizes depending on the preference of the consumer.

The length of the fruit ranged from 10.26 to $24.51 \mathrm{~cm}$, while fruit diameter varied from 10.62 to $22.51 \mathrm{~cm}$. The total soluble solids content ranged from 4.03 to $9.43^{\circ}$ Brix, with accessions UENF
1864, UENF 1875, UENF 1862, UENF 1881, and UENF 1895 showing the highest values of 9.43, 8.77, 7.77, 7.33, and $7.18{ }^{\circ}$ Brix, respectively. Ramos et al. (1999) observed high levels of total soluble solids in studied accessions of C. moschata, revealing a preference by producers in the Brazilian northeast for sweeter fruits. In the center-south, the Tetsukabuto hybrid is preferred, with solids levels ranging from 5.2 to $6.8^{\circ} \mathrm{Brix}$ (PEDROSA, 1981).

The weight of 100 seeds ranged from 4.59 to $15.55 \mathrm{~g}$ in accessions UENF 1895 and UENF 1879. For pulp thickness, the values ranged from 1.97 $\mathrm{cm}$ (UENF 1886) to $11.79 \mathrm{~cm}$ (UENF 1875) on the peduncle, $1.21 \mathrm{~cm}$ (UENF 1875) to $4.39 \mathrm{~cm}$ (UENF 1889) on the middle, and $1.05 \mathrm{~cm}$ (UENF 1875) 3.07 
cm (UENF 1893) on the bottom. Flesh thickness is an important characteristic as fruit that produces thicker pulp produces higher income, which is an important commercialization and industrialization factor. Blank et al. (2013) evaluated flesh thickness in seven genotypes of pumpkin and measured values of 2.20 to 33.61 for the side of the stalk, 1.65 to 5.30 in the middle, and 2.30 to 8.19 on the bottom.

UPGMA hierarchical grouping (Figure 1) revealed a higher cophenetic correlation coefficient
(CCC: 0.81) than that observed for the nearest neighbor (CCC: 0.59) and Ward grouping methods (CCC: 0.58). These results agree with those obtained by Gonçalves et al. (2008) and Rocha et al. (2009, 2010). According to Sokal and Rohlf (1962), correlations higher than 0.80 indicate a good fit between the original distance matrix and those derived from graphic distances, reinforcing the higher reliability of the UPGMA method.

Figure 1. Dendrogram of genetic dissimilarities among 14 accessions of pumpkin obtained using the UPGMA method based on Gower's algorithm from qualitative and quantitative variables.

\section{Genetic Distance}

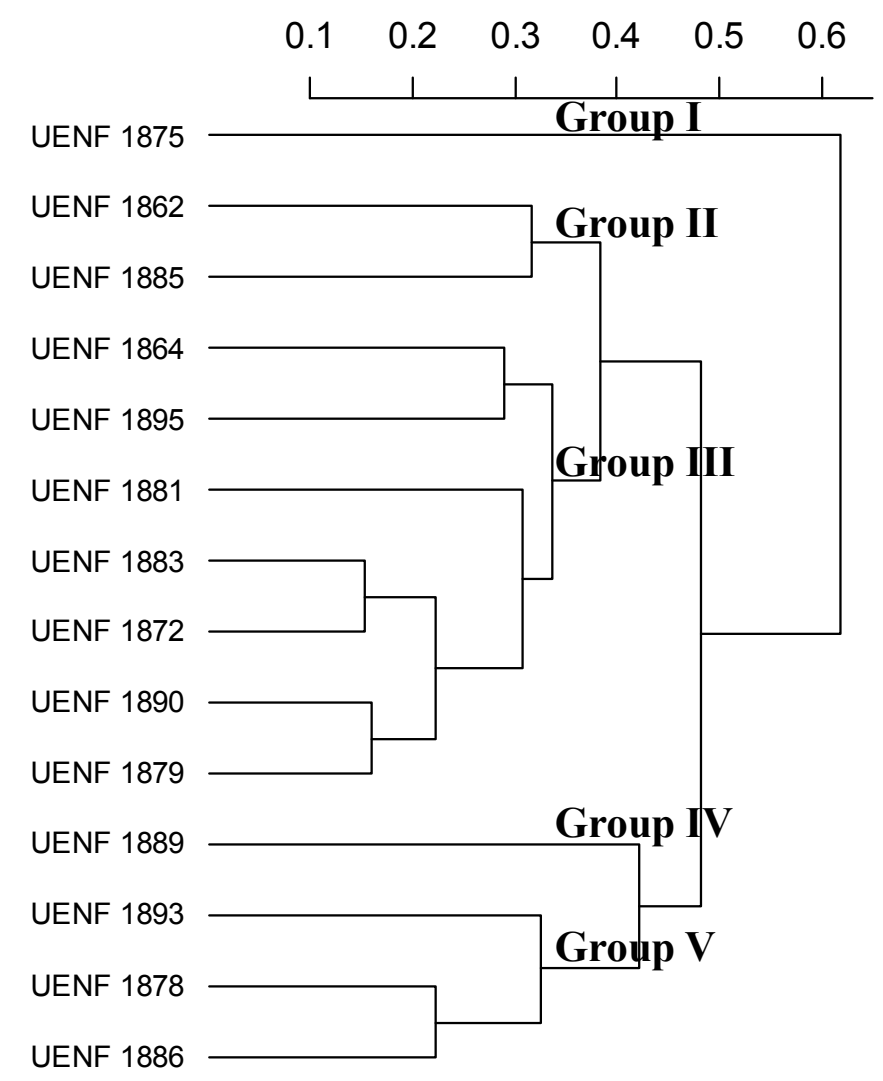

A cut-off distance of 0.38 , taking into account the point of abrupt change, resulted in the formation of five groups. Accession UENF 1875 (group I) was the most divergent compared to other accessions. This accession showed lower fruit mass (0.97 $\mathrm{kg}$ ) and higher pulp thickness in the stalk (11.79 $\mathrm{cm})$. For qualitative characteristics, this accession showed small leaves and very sharp elliptic seeds. The fruit of this accession was pear-shaped with orange skin color and intermediate ribs. 
Group II was formed by accessions UENF 1862 and UENF 1885, which feature intermediate-sized leaves, sharply elliptical and yellow color seeds, heart-shaped fruits, green skin coloring, and orange pulp. Accession UENF 1862 includes fruits with a mean body mass of $1.44 \mathrm{~kg}$, length of $21.19 \mathrm{~cm}$, diameter of $13.24 \mathrm{~cm}$, and total soluble solids content of $7.77^{\circ}$ Brix, while accession UENF 1885 had an average mass of $2.93 \mathrm{~kg}$, length of 24.51 $\mathrm{cm}$ length, diameter of $17.35 \mathrm{~cm}$, and total soluble solids content of $5.23^{\circ}$ Brix.

Group III was composed of seven accessions (UENF 1864, UENF 1872, UENF 1879, UENF 1881, UENF 1883, UENF 1890, and UENF 1895). This group had masses ranging from 1.05 to 2.09 $\mathrm{kg}$ and a soluble solids content between 4.77 to $9.43^{\circ}$ Brix. The length and diameter of the fruit ranged from 10.26 to $19.18 \mathrm{~cm}$ and 13.46 to 15.11 $\mathrm{cm}$, respectively. Stalk, middle, and bottom pulp thickness showed lower and upper limits of 2.01 to $3.99 \mathrm{~cm}, 1.74$ to $2.29 \mathrm{~cm}$, and 1.09 to 2.19 , respectively. The predominant color of the pulp was orange and the skin was green. Most accessions had superficial ribs. High variation was observed in fruit shape among accessions in this group, with three accessions showing an elliptical shape, two globular, and two pyriform.

Group IV included only accession UENF 1889, which produced fruit with the highest mass (4.79 $\mathrm{kg}$ ) and lowest total soluble solids content $\left(4.03^{\circ}\right.$ Brix) among the accessions evaluated. With regard to the length and diameter of the fruit, weight of 100 seeds, and pulp thickness in the stalk, middle, and bottom, the accession displayed the following values: $18.87 \mathrm{~cm}, 22.51 \mathrm{~cm}, 8.72 \mathrm{~g}, 4.39 \mathrm{~cm}, 4.39$ $\mathrm{cm}$, and $2.38 \mathrm{~cm}$, respectively. For qualitative data, the accession had large leaves, brown elliptical seeds, globular fruit, and orange skin and pulp.

Group V was formed by three accessions (UENF 1878, UENF 1886, and UENF 1893), with weights varying between 2.94 to $4.09 \mathrm{~kg}$ and total soluble solids content from 4.9 to $5.57^{\circ}$ Brix. The fruit length and diameter ranged from 13.76 to 22.37 $\mathrm{cm}$ and 18.31 to $22.00 \mathrm{~cm}$, respectively. Regarding qualitative data, high homogeneity was observed, and all members had large leaves, sharply elliptical seeds, whitish, globular fruits, and smooth skin texture. The flesh color of accession UENF 1893 had an orange hue, while accessions UENF 1878 and UENF 1886 were reddish-orange. Accession UENF 1878 had superficial ribs, accession UENF 1886 had intermediate ribs, and accession UENF 1893 had deep ribs.

Variability was observed among accessions collected from rural properties in the northern region of the state of Rio de Janeiro, and Gower's distance (GOWER, 1971) together with UPGMA analysis allowing for good discrimination of accessions into groups, demonstrating that the simultaneous analysis of quantitative and qualitative data is feasible and may allow enable the efficient analysis of the variability among accessions.

The distance proposed by Gower is a lowcomplexity procedure and has been shown to produce robust results in several studies, although it is not frequently used by plant genetics researchers to detect variability in germplasm banks. Some studies have described the use of this methodology, including Rodriguez et al. (2005), in an investigation of Brassica napus L, Vieira et al. (2007) and Bertan et al. (2009) in a study of Triticum aestivum L., Gonçalves et al. (2008) and Rocha et al. (2010) in an evaluation of Solanum lycopersicum, Tsivelikas et al. (2009) in a study with Cucurbita spp., and Moura et al. (2010) in a study of Capsicum chinense.

\section{Conclusions}

There is variability among pumpkin landraces collected from rural properties in the northern region of the state of Rio de Janeiro. Gower's distance together with UPGMA allowed for discrimination of accessions into groups taking into account the joint analysis of qualitative and quantitative variables. 


\section{References}

BERTAN, I.; CARVALHO, F. I. F. de; OLIVEIRA, A. C. de; BENIN, G.; VIEIRA, E. A.; VALÉRIO, I. P. Morphological pedigree, and molecular distances and their association with hybrid wheat performance. Pesquisa Agropecuária Brasileira, Brasília, v. 44, n. 2, p. 155-163, 2009.

BLANK, A. F.; SILVA, T. B.; MATOS, M. L.; CARVALHO FILHO, J. L. S.; SILVA-MANN, R. Parâmetros genotípicos, fenotípicos e ambientais para caracteres morfológicos e agronômicos em abóbora. Horticultura Brasileira, Brasília, v. 31, n. 1, p. 106-111, 2013.

CABRAL, P. D. S.; SOARES, T. C. B.; GONÇALVES, L. S. A.; AMARAL JÚNIOR, A. T. do; LIMA, A. B. P.; RODRIGUES, R.; MATTA, F. de P. Quantification of the diversity among common bean accessions using Ward-MLM strategy. Pesquisa Agropecuária Brasileira, Brasília, v. 45, n. 10, p. 1124-1132, 2010.

CARVALHO, P. G. B.; PEIXOTO, A. A. P.; FERREIRA, M. A. J. F. Caracterização de abóboras quanto aos teores de carotenoides totais, alfa-e bata-caroteno. Brasília: Embrapa Hortaliças, 2011. 20 p.

DE-POLLI, H. Manual de adubação para o estado do Rio de Janeiro. Seropédica: UFRRJ, 1990. 179 p.

ESQUINAS-ALCAZAR, J. T.; GULICK, P. J. Genetics resources de Cucurbitaceaes. Rome: IBPGR, 1983. 101 p.

FILGUEIRA, F. A. R. Novo manual de olericultura: agrotecnologia moderna na produção e comercialização de hortaliças. Viçosa, MG: UFV, 2000. 189 p.

GONÇALVES, L. S. A.; RODRIGUES, R.; AMARAL JÚNIOR, A. T. do; KARASAWA, M.; SUDRÉ, C. P. Comparison of multivariate statistical algorithms to cluster tomato heirloom accessions. Genetics and Molecular Research, Ribeirão Preto, v. 7, n. 4, p. 12891297, 2008.

GOWER, J. C. A general coefficient of similarity and some of its properties. Biometrics, Arlington, v. 27, n. 4, p. 857-874, 1971.

MOURA, M. da C. C. L.; GONÇALVES, L. S. A.; SUDRÉ, C. P.; RODRIGUES, R.; AMARAL JÚNIOR, A. T. do; PEREIRA, T. N. S. Algoritmo de Gower na estimativa da divergência genética em germoplasma de pimenta. Horticultura Brasileira, Brasília, v. 28, n. 2, p. 155-161, 2010.

PARIS, H. S.; BROWN, R. N. The genes of pumpkin and squash. Hortscience, Virgínia, v. 40, n. 6, p. 1620-1630, 2005.
PARIS, H. S.; PADLEY JÚNIOR, L. D. Gene list for Cucurbita species. [S.1.: s.n.], 2014. Available at: $<$ http:// cuke.hort.ncsu.edu/CGC/cgcgenes/gene14squash.pdf>. Accessed at: 13 jun. 2015.

PEDROSA, J. F. Caracterização agronômica $e$ qualitativa de plantas e frutos de introdução de C. maxima e C. moschata. 1981. Tese (Doutorado em Agronomia) Universidade Federal de Viçosa, Viçosa, MG.

PEIXOTO, N. Melhoramento genético de abóbora (Cucurbita moschata Duch.) do grupo baianinha. I. Obtenção, seleção de linhagens e avaliação de híbridos $F_{1}$ braquíticos. 1987. Dissertação (Mestrado em Agronomia) - Universidade Federal de Viçosa, Viçosa, MG.

QUINTAL, S. R.; VIANA, A. P.; GONÇALVES, L. S. A.; PEREIRA, M. G.; AMARAL JÚNIOR, A. T. do. Divergência genética entre acessos de mamoeiro por meio de variáveis morfoagronômicas. Semina: Ciências Agrárias, Londrina, v. 33, n. 1, p. 131-142, 2012.

RAMOS, S. R. R.; QUEIRÓZ, M. A.; CASALI, V. W. D.; CRUZ, C. D. Recursos genéticos de Cucurbita moschata: caracterização morfológica de populações locais coletadas no Nordeste brasileiro. In: QUEIRÓZ, M. A.; GOEDERT, C. O.; RAMOS, S. R. R. (Ed.). Recursos genéticos e melhoramento de plantas para o Nordeste Brasileiro. Petrolina: Embrapa Semi-Árido, 1999. Disponível em: <https://www.alice.cnptia.embrapa.br/ alice/handle/doc/153831> Aesso em: 13 jun. 2015.

ROCHA, M. C.; GONÇALVES, L. S. A.; CORRÊA, F. M.; RODRIGUES, R.; SILVA, S. L.; ABBOUD, A. C. S.; CARMO, M. G. F. do. Descritores quantitativos na determinação da divergência genética entre acessos de tomateiro do grupo cereja. Ciência Rural, Santa Maria, v. 39, n. 3, p. 664-670, 2009.

ROCHA, M. C.; GONÇALVES, L. S. A.; RODRIGUES, R.; SILVA, P. R. A. da; CARMO, M. G. F. do; ABBOUD, A. C. S. Uso do algoritmo de Gower na determinação da divergência genética entre acessos de tomateiro do grupo cereja. Acta Scientiarum Agronomy, Maringá, v. 32, n. 3, p. 423-431, 2010.

RODRÍGUEZ, V. M.; CARTEA, M. E.; PADILLA, G.; VELASCO, P.; ORDÁS, A. The nabicol: a horticultural crop in northwestern Spain. Euphytica, Wageningen, v. 142, n. 3, p. 237-246, 2005.

SANTOS, J. O. Adaptabilidade e estabilidade de précultivares de abóbora (Cucurbita moschata D.) nas condições do norte e do noroeste fluminense. 2013. Tese (Programa de Pós-Graduação em Genética e Melhoramento de Plantas) - Universidade Estadual do Norte Fluminense Darcy Ribeiro. Campos dos Goytacazes. 
SANTOS, M. H. dos; RODRIGUES, R.; GONÇALVES, L. S.A.; SUDRÉ, C. P.; PEREIRA, M. G. Agrobiodiversity in Cucurbita spp. landraces collected in Rio de Janeiro assessed by molecular markers. Crop Breeding and Applied Biotechnology, Viçosa, MG, v. 12, n. 2, p. 96103, 2012.

SCOTT, A. J.; KNOTT, M. A cluster analysis methods for grouping, means in the analysis of variance. Biometrics, Arlington, v. 30, n. 3, p. 507-512, 1974.

SOKAL, R. R.; ROHLF, F. J. The comparison of dendrograms by objective methods. Taxon, Michigan, v. 11, n. 1, p. 33-40, 1962.

SUDRÉ, C. P.; GONÇALVES, L. S. A.; RODRIGUES, R.; AMARAL JÚNIOR, A. T. do; RIVA-SOUZA, E. M.; BENTO, C. S. Genetic variability in domesticated Capsicum spp. as assessed by morphological and agronomic data in mixed statistical analysis. Genetics and Molecular Research, Ribeirão Preto, v. 9, n. 1, p. 283-294, 2010.

TSIVELIKAS, A. L.; KOUTITA, O.; ANASTASIADOU, A.; GEORGE, N.; SKARACIS, G. N.; TRAKAMAVRONA, E.; KOUTSIKA-SOTIRIOU, M. Description and analysis of genetic diversity among squash accessions. Brazilian Archives of Biology and Technology, Curitiba, v. 52, n. 2, p. 271-283, 2009.

VIEIRA, E. A.; CARVALHO, F. I. F. de; BERTAN, I.; KOPP, M. M.; ZIMMER, P. D.; BENIN, G.; SILVA, J. A. G. da; HARTWIG, I.; MALONE, G.; OLIVEIRA, A. C. de. Association between genetic distances in wheat (Triticum aestivum L.) as estimated by AFLP and morphological markers. Genetics and Molecular Biology, Ribeirão Preto, v. 30, n. 2, p. 392-399, 2007. 